\title{
Urbanization and the Development of Informal Activities in the City of Bamenda and Environs, 1988-2010
}

\author{
Protus Mbeum Tem, Ph.D. ${ }^{1}$, Milton Abawah Ndambi ${ }^{2}$
}

${ }^{1}$ The University of Bamenda, Cameroon

${ }^{2}$ Postgraduate student, The University of Bamenda, Cameroon

Received: 04 Nov 2020; Received in revised form: 28 Dec 2020; Accepted: 11 Jan 2021; Available online: 16 Jan 2021 (C2021 The Author(s). Published by The Shillonga Publication. This is an open access article under the CC BY license (https://creativecommons.org/licenses/by/4.0/).

\begin{abstract}
Urbanisation has been one of the greatest ingredients for the proliferation of informal activities in developing countries in general and Cameroon in particular. This has been catalysed by increase in population as individuals tussle for economic survival. This is true with the case of the city of Bamenda and environs where informal activities constituted the thrust of economic occupations between 1998 and 2010. With the advent of economic crisis in Cameroon in 1988 and ensuing economic hardship, migrants anticipating for myriad opportunities moved into the area. However, their desires were shattered when they would not find or catchup with their desired dreams. The resultant effect was the quest for informal activities that would provide for their livelihoods and better their standards of living. It is because of this that the study contends that, though the inception of the economic crisis in Cameroon and the budding educational establishments in Bamenda and environs facilitated population growth and urbanisation of the area as well as the proliferation of informal activities, increased crimewaves, unemployment, poor infrastructural development, poor living standards, high cost of transportation and administrative bottlenecks, inadequate finances and the unstable nature of students' residencies were impedimental to the benefits that goes along with such developments and greatly worked against the advancement of the area.
\end{abstract}

Keywords-Urbanisation, informal activities, Bamenda, growth and employment opportunities.

\section{INTRODUCTION}

Urbanization has become one of the major catalysts for the development and growth of informal activities in Africa and the trend has been rapid when compared to other parts of the world with the exception of Asia. Though largely rural, the process has recorded an unprecedented swift over the years. With less than $10 \%$ of its population living in urban areas before1950, the level of urbanization increased to about $18.5 \%$ in the 1960 s and by 2000 it had risen to about $37.2 \%$. Today, urbanization in the continent stands at about $40 \%$ and

\footnotetext{
${ }^{1}$ See Joseph Teye. Urbanisation and Migration in Africa. (Expert Group Meeting, United Nations Headquarters in New York, 1-2 November, 2018), 2; Burak G"uneralp, Shuaib Lwasa, Hillary Masundire, Susan Parnell and Karen C Seto. Urbanization in Africa: challenges and opportunities for Conservation. (Environmental Research Letters: 13, 2018, 1-8); United Nations. World urbanization prospects: The 2001 revision. (New York: Upper Saddle River, 2002); United Nations. World urbanization prospects: The 2003 revision. (New York: Upper Saddle River, 2004); UNDESA (United Nations
}

it has been forecasted to $60 \%$ by $2050 .{ }^{1}$ Urbanisation is not a new phenomenon as its traces its roots to indigenous or precolonial Africa contrary to European apologists, who posits that it is linked colonialism. To them, indigenous Africa lacked the necessary sophisticated political, economic and social organisations, that is associated with the growth and development of towns. They attributed urbanisation to civilisation which they believed to be absent in Africa before European interferences.

Department of Economic and Social Affairs). World Urbanization Prospects: 2014 Revision. (New York: United Nations Department of Social and Economic Affairs, 2014); UNDP (United Nations Development Programme). Human Development Report 2015: Work for Human Development. (New York: United Nations Development Programme, 2015) and Mohamed Arouri, Adel Ben Youssef, Cuong Nguyen-Viet and Agnès Soucat. "The Effects of Urbanization on Economic Growth and Human Capital Formation in Africa" (PGDA Working Paper No. 119, (2014) 2 for more details. 
However, urbanization was part and parcel of developments in the continent before European interference. This argument can be sustained with that fact that many cities or urban centres developed and were shaped by natural and human or better still socio-political factors in all the regions of Africa. Most prominent historical centres worthy of exemplifying included; Cairo, Fez and Tripoli in North Africa. In West Africa, Timbuktu, Kumasi, Ife, Kanem, Jenne and Kano thrived and in East and Southern Africa, Great Zimbabwe, Kilwa, Mombasa, Kongo, Luba and Kuba were conspicuous. These and other urban centres dispel the view that the development of towns in Africa was as a result of colonialism and western meddling or intrusions. ${ }^{2}$

That notwithstanding, European Presence by 1400 brought new opportunities which altered urbanisation trends in the continent. The establishment of transportation networks, new administrative centres and plantations and mining opportunities facilitated migrations and consequently the development of new urban centres. In Cameroon, the case of Doula and Victoria (Limbe) can be cited as these centres developed into cities due to the presence of habours that were needed by the colonialists in the facilitation of the exportation of resources. Besides, the construction of roads and railways to centres or areas of production also facilitated the movement of people from different part of the colony to these destinations. Better still, other towns developed because they were administrative centres like the case of Yaounde which became the capital of French Cameroun.

With regard to the area of study, the city of Bamenda hosted the administrative headquarters of German Kamerun in the Western Grasslands. With the departure of the Germans after World War I, in 1916, and the inception of British rule, Bamenda still maintained its status as the administrative headquarter of the Region (Bamenda Province) until 1961 when the territory attained independence. Since then it has remained the Regional (Provincial) capital of the North West. Besides, the area gained more impetus when Bamenda was upgraded to an Urban Council in 1992. With the creation of the University of Bamenda in 1910, more people migrated into the area. The status accorded the study area, over the years, became great ingredients in its growth and urbanisation as it became the hub of economic, social and political

\footnotetext{
${ }^{2}$ For more details on the development of Urbanisation in indigenous Africa, See Suzanne Preston Blier. The African Urban Past Historical Perspectives on the Metropolis in David Adjaye. Ed. African Metropolitan Architecture (London: Thames and Hudson, 2012) and Hull, R. W. African cities and towns before the European conquest. (New York: W. W. Norton \& Company Inc, 1976).
}

activities of Mezam the North West Region in general and Mezam Division in particular.

From the ongoing analysis, one may believe that the development of urban centres anchors on or are influenced by administrative functions of localities but this is not true as such developments are also attributed to modernism. According to the Western Liberal view, people within the peripheries are attracted to areas where job opportunities are available. In essence, economic challenges and most notably unemployment are the main drivers for migration. Besides the quest for better education and other social amenities as well as political factors which are; "quality of governance, discrimination or persecution, levels of security and policy incentives"3 among others are some of the reasons for migration leading to the intense proliferation of informal activities in most urban towns and cities around the world. By implication, urbanization is associated with many pull and push factors such as the growth of industries, infrastructural development, the establishment of institutions where new skills can be acquired such as schools and the search for better living standards. Thus, urbanisation brings varying economic opportunities, social amenities as well as infrastructural advancement. In analysing the contributions of informal sector to development, Romanos and Chifos posits that the solid waste collection, disposal, and recycling; water provision; improving air quality; and greening through urban agriculture are the most visible outcomes. ${ }^{4}$

With the expectation of enjoying these benefits that went along with urbanisation, many migrated into Bamenda and its environs but did not experienced better lives as they perceived. Unemployment, poor infrastructural development, high crime waves, and poverty as well as poor living standards bisected their new found land and in a bid to offset these setbacks and improve on their wellbeing, they resorted to informal activities. Better still, since most of the migrants could no longer cleave to agriculture as was the tradition in their formal abbots, they had to search for alternative methods or techniques of survival and informal activities became the only means of livelihood. This phenomenon which has affected Bamenda city and its environs (Bambui and Bambili in Tubah Subdivision) has been on the increase since 1988 with its associated problems. This explains why the paper analysis the Urbanization and the development of informal

\footnotetext{
3 Joseph Teye and Mariama Awumbila. Factors ff Migration and Urbanization in Africa. (Centre For Migration Studies, University of Ghana, 2014), 11.

${ }^{4}$ Romanos, M. and C. Chifos. Contributions of the urban informal sector to environmental management. Regional Development Dialogue, 17: 1 (1996), 122-155.
} 
activities as well as the downside of this phenomenon between 1998 and 2010.

\section{CONCEPTUAL FRAME WORK}

It is difficult to, define and measure the dimensions of informal activities as these are as varied as authors involved in documenting information related to the sector. According to Schneider, Buehn and Montenegro, the informal sector or activities has to do with market-oriented production activities which are hidden from state authority and characterised by the none payment of taxes and social security contributions. The respect of labour regulations with regards to market standards is nil. In this connection, minimum wages, maximum working hours, safety standards are not in line with the set down rules and regulations. Administrative procedures, such as the completing of statistical questionnaires or other administrative forms or better still getting information on the activities of the sector by the state, is often difficult. ${ }^{5}$ The term can best be understood on the description given by Hart. To him, the informal sector is an embodiment of the economic activities of self-employed individuals since it excludes those of unregulated firms with salaried employees. ${ }^{6}$

The structuralist view on the informal sector, as indicated by ILO in 1985, holds that this sector can best be explained or characterized by many factors among which are issues of engaging or starting a business and ownership. To this end, the family is sole concerned and resources are directed towards it. Again, the ILO further argues that activities performed by destitute people (those at the periphery of society) for survival are considered informal. The ILO branded the sector with different names or attributes by 1999 and these included; the shadow economy, irregular economy, petty commodity production, underground economy among other characteristics. ${ }^{7}$ However, by 2002 the ILO decided to include the issue of decent work. This approach saw the informal sector as a bridge on which workers passed from one sector to another; that is from the agricultural labour force to other sectors considered modern. ${ }^{8}$

Ranis and Stewart described informal activities as the sector which includes only small-scale enterprises. ${ }^{9}$ Amin summarises the meaning of informal activities and

${ }^{5}$ Schneider, F., Buehn, A. and Montenegro, C. E. New Estimates for the Shadow Economies all Over the World. International Economic Journal, 24 (4), (2010). 443-461.

${ }^{6}$ Hart K. Small Scale Entrepreneurs in Ghana and Development Planning, Journal of Development Studies, 28, (1970), 705-716.

${ }^{7}$ International Labour Office, Informal Sector in Africa. ILO/JASPA, Addis Ababa, (1985), 5. differentiates it from the formal sector when he argues that the informal sector is visible through;

(i) certain labor and employment characteristics (such as lack of official protection/recognition, lack of coverage by wage legislation and other social security systems, predominance of own-account work; absence of trade union organization, low income and wages, little job security, and absence of fringe benefits from institutional sources); (ii) enterprise operation characteristics (such as very small-scale operation, unregulated and competitive market, reliance on locally available resources, family ownership, labor-intensive and adapted technology, and absence of access to institutional source of credit and similar support or protection); and/or (iii) land and housing characteristics of settlements (such as unauthorized use of vacant land, illegal subdivisions/renting of land, unauthorized construction, reliance on cheap and locally available scrap construction techniques, lack of application of safety standards and regulations, and nonavailability of mortgages or any other financing) (Amin 1996). ${ }^{10}$

This therefore gives a vivid understanding of the informal sector and the study hinges on these arguments in describing the informal sector or activities that are operational and not covered or sufficiently covered by formal and legal frameworks and arrangements in the city of Bamenda and environs.

\section{Enabling Vectors for Informal Activities in the City of Bamenda and Environs}

The City of Bamenda and its environs remained relatively backward, with regard to urbanisation, when compared to other towns and cities in Cameroon by the 1990s. it was uncommon to find major industries operating in the area and thus difficult for its inhabitants to find opportunities. Though imbued with educational facilities which laid for the bases for infrastructural development and population growth, the urbanisation process remained relatively slow. The absence of industries and formal activities left the people with little or no choice than to engage in opportunities permitted by the local environment. With this, they engaged in pottery, weaving,

8 ILO $15^{\text {th }}$ International Conference of Labour Statisticians: Highlight of the Conference and Text of the Three Solutions Adopted. Geneva: Bulletin of Labour Statistics, (1992-2000).

10 Amin, A. T. M. N. The informal sector paradigm: Analytical contributions and developmental role, Regional Development Dialogue 17(1) (1996, Spring), xvii. 
hunting, fishing, craft, livestock rearing, blacksmithing, tapping and agriculture which was the dominant economic activity of the area. ${ }^{11}$ Production was purely for subsistence and the excesses were use in exchange for basic necessities like salt and clothes. ${ }^{12}$

As mentioned before now, the agricultural sector remained the mainstay of the economy of Cameroon in general and Bamenda in particular. Coffee remained the main crop produced in the area and the main foreign earnings for the people and of the area and the state. Together with other agricultural products like cocoa, rubber and also natural resources such as oil, the State was able to maintain and sustained higher living standards for its people in the 1970s and first half of the 1980s. However, the sudden fall in the prize of oil and agricultural products in the world market in the 1980s rendered a negative effect on the economy of the country. The economic crisis set in and the government had no choice but sought for a bail out from the international financial market and the process began by the end of the decade (1988). ${ }^{13}$

Consequently, the government embraced the structural adjustment programs proposed by the International Monetary Fund and World Bank. With this, the CFA Francs currency that was legal tender was devalued. This was in a bid to increase the competitiveness of Cameroon products in the World Market. To reduce government expenditures, staffs on the state's payroll were layoff. Besides, the liberalization of the economy saw the privatization of state-owned corporations. To sum it all, this was to reduce government spending and offset budgetary deficits witnessed over the years ${ }^{14}$. As per the International Monetary Fund and World Bank, this was the best way out to regenerate growth and economic development in the country. Better still, these measures were seen as magic solutions to the crisis. ${ }^{15}$

Unfortunately, these measures did not work produced the desired goals in the short term but rather exacerbated the already aggrieved economic situation in the country and especially in the urban areas where depended on white collar jobs for survival. With this unfortunate situation, most of the inhabitants of Bamenda and environs were affected by these economic policies directly or indirectly. Some of them lost their jobs and others engaged in the

\footnotetext{
${ }^{11}$ NAB, Ad, (1927)4a, N0.277'/27, Assessment Report of Mezam Area in the Bamenda Division, Cameroon Province, 1927, 24.

${ }^{12}$ Ibid, 24.

13 Aloysius Ajab Amin. Cameroon's Fiscal and Economic Growth. (African Economic Research Consortium. Paper 85, November 1998), 4.

${ }^{14}$ Ibid, 24.
}

agricultural and related sectors were trapped in these new developments. This economic quack mire forced some of the embraced informal activities not because they liked it but as the only means of survival. They were joined in these activities by people from different localities that were equally affected by the crisis and in for new opportunities. This development greatly increased the population of the area in general and those engaged in informal activities.

Hence, this became the main nexus to the growth of Bamenda town and those of Bambui and Bambili as most people moved into the to mitigate the socio-economic challenges caused by the economic crisis and measures aimed at eradicating it. The trooping of people into Bamenda and environs from different backgrounds did not only swell the population but also impacted on the growth and expansion of the area as it became urbanised and facilitated the development of informal activities.

\section{Urbanisation and the Nexus to Informal Activities}

With the inception of the economic crisis, the area of study witnessed an unprecedented growth in population and the proliferation of informal activities. This drive is associated with the retrenchment of civil servants by the government and state-owned corporations. By 1995, moves were made the government in reducing those on the government payroll. About 30,000 workers were previewed for retrenchment and were to be offered 24 months of their basic salaries on their departure. Kamanda argues that the workers were offered two months of salary arrears (September and October) owed them in 1993 among other benefits. Consequently, by May 1995, there was a considerable drop in the numbers of public service workers from 188,200 (in 1990) to $155,210 .{ }^{16}$ Hence, the retrenched workers who moved into Bamenda and environs made use the money in financing or engaging in informal activities.

Besides, those who remained in the payroll of the government saw their salary slashed and life became unbearable for them. In this connection, they had no choice but engage in activities that would enable them meet up with their needs. This argument can be sustained with the case of retrenched Cameroon Development cooperation (C.D.C) workers that were from the North West Region of Cameroon returned to this growing urban town of Bamenda with the

\footnotetext{
${ }^{15}$ George B. A. Ayetty, Africa in chaos. (New York, United States of America: St Martin's Graffin, 1998), 22.

${ }^{16}$ Bayie Kamanda, "Cameroon: The Retrenched Workers of the Civil Service and Parastatals. Assessing the Needs for the Reforms". Bulletin de l'APAD [Online], 18, 1999, Accessed on 07 September 2020, 4.
} 
hope of getting new opportunities. They and other ex-state employees could not find the cherished opportunities and took shade in the informal sector. ${ }^{17}$ Added to these, devaluation meant appreciation in actual terms with regard to the purchasing power of citizens. This had a serious negative consequence on the purchasing power of citizens and the ability to provide for their basic wants, leaving them with little or no choice than engaging in informal activities in order to augment. This explains why many of them trooped into Bamenda where the climate was rosy for such developments. It therefore means that the implication of government policy affected the formal sector as some of those involved in the sector found solace in informal activities.

They joined others already engaged in the sector in intensifying informal activities. Nigerians, especially from the Igbo ethnic groups as well as the Bamilekes from the Western Region of Cameroon strengthened informal activities as most of them were involved in the retail businesses and pettitrading. Neighbourhoods like Old Town in Bamenda, Commercial Avenue were their fiefs. Their presence and successes also encouraged some indigenes and settlers who hitherto had no interest in these activities. They showed renewed interest in the sector and established shops and competed with them. ${ }^{18}$ It should be stated categorically clear that there existed only a handful of people that undertook these informal activities based on choice, the proportion of those who were driven by necessity and for survival was very significant. This was a basically done within the Township area of Bamenda but as population pressure increased within Bamenda other towns began emerging. The quest for the provision of social services by the population also increased. In response, government began establishing institutions these in nearby villages in a bid to decongest the urban centre of Bamenda. This gave rise to the development of other villages into urban centres. ${ }^{19}$ Remarkably, the Bambui and Bambili are worth citing as they gradually grew into urban centres and the economy dominated by informal activities.

The emergence of Motorcycling as an economic activity or better still, as a means of public transport in Cameroon seriously impacted on the informal sector. Some of the unemployed as well as those engaged in unproductive informal activities switched to motorcycling and by 2000 , it had become one of the most employing sectors in the area of study. Besides, other associated trades benefitted from this development as evident in the development of businesses

\footnotetext{
${ }^{17}$ Francis Azang Mboh, 51 Years, Trader, Nkewn, 25/09/2017; Charles Tifor Katu, 43 Years, Carpenter, Bambui, 19/09/2017; Mbanong Fedelis Andre, 60 Year, Farmer, Bamenda, 21/07/2017
}

related to the sales of motorbike parts, accessories and repair works (garages). These were found in almost all neighbourhoods and localities like Old town and Commercial Avenue in Bamenda took the lead. The imposing influence of these activities in Bambui and Bambili towns cannot be overemphasized. Added to these developments, the mobile phone sector also witnessed considerable growth and its effects impressive with regard to the informal sector. Intensity in this direction came after 2006 when the activities of the Mobile Telecommunication Network (MTN) and Orange Cameroon brought another dimension in the informal sector.

With this, some youths began running 'call boxes' (temporary boxes or posts stationed mostly along major road junctions) where communication credits and related services were marketed. This became one of the most conspicuous sectors that developed after 2000 as it engulfed some of the unemployed in the City Bamenda, Bambui and Bambili. It was common to see youths stationed in makeshift boxes or rooming the streets with insignias indicating the services offered. Their activities were concentrated but not limited to of areas of high population density and were visible in markets, motor parks and major junctions. In this direction, Food Market, Commercial Avenue, city chemist Round About, all in Bamenda, Four Corners, Bambui and Three Corners, Bambili among others were the hubs of their activities. Worth noting is the fact that some people engaged in both the motorbike and call box activities especially when income generated from one of these sectors would not meet up with their basic necessities.

Informal activities also gained steam with the creation of The University of Bamenda in 2010. Informal real estate businesses which hitherto was not conspicuous before then but things took a different dimension as the demand for land and housing facilities increased. This was caused by rapid growth of or urbanization due to increase in population (increase in the number of students, teachers and other individuals searching for opportunities). Most importantly, Bambili which hosted the institution was affected the most. Also, Bambui which was the nearest neighbour to Bambili and separated the former with the city of Bamenda also benefited from these developments. With these came other services. Cognisance is tailored towards the establishment of documentation centres where printing, typing, photocopying, scanning among other related services developed. Internet centres also developed as internet facilities were offered to the

${ }^{18}$ Edem
${ }^{19}$ Edem 
community. Though visible in all the towns under focus, Bambili has been singled out as the main centre of these activities when compared to their neighbours. Hence, with the coming of The University of Bamenda, many people within Bambili and Bambui started shifting from agriculturallyoriented based activities to other forms of informal economic activities as mention above. Thousands of youths and adult also abandoned farming in favour of the above-mentioned activities.

Cobbling or shoe mending became a lucrative activity as well restaurants as the demand for food and cobbling services were in high demand. This does not mean that these activities were uncommon in the areas before the creation of the university but they became entrenched after 2010. With these outcomes, one can argue that what started as informal activities before 1988, turned out to be more vibrant and with greater intensity, impacted so much on the economic development of Bamenda and towns environs.

\section{Downsides of Urbanisation and Growth of Informal Activities}

Although urbanisation greatly contributed to the rise of informal activities, such developments were associated some downsides. To begin with, transportation cost and administrative bottlenecks constituted the major impediments to informal businesses in the area. Complications in relation to the normalisation of businesses from informal to formal, stole the show. The procedure became long and complicated and operators within the sector ended up abandoning the urge for normalisation. They preferred operating illegally especially when they discovered that taxes to be paid were relatively high when compared to the proceeds from their businesses. By implication, the taxes levied on their business were exorbitant and did not take into consideration local business realities. ${ }^{20}$ Taxation teams visited regularly for assessment, levying and collection of taxes with little or no consideration on the realities on the ground. According to Freddy, a business operator, the taxation teams that came for assessments most often had little or no knowledge on the business climate or different challenges facing businesses within their localities, especially those around Bambui and Bambili where he operated. As a result, taxes levied were usually very high making profit maximisation difficult. Things were further compounded by price control teams that constantly demanded bribes from businessmen in exchange of favours during subsequent outings.

Constant harassment and exploitation of business operators by security forces and taxation officials became a

${ }^{20}$ Charles Tifor Katu, 43 Years, Carpenter, Bambui, 19/09/2017. persistent threat to the existence of the sector. Operators in informal activities who had not normalised their business situations became victims and had no choice than to pay bribes for the continuance of their activities. This explains why shops sealed for operating illegally were unsealed without owners legalising their situations. Thus, an unhealthy climate existed between local authorities and operators especially on issues related to the activities and methods of operations. The local authorities favoured a situation where revenue would be mobilized from informal workers in the form of market tolls, fees and licensing. At the same time, authorities wanted to get rid of informal workers especially street vendors, partly due to perceived negative impacts on urban planning and management. They were also considered as nuisance and accused of not contributing to the development of their areas as they constantly default on tax payments. As such, measures such as payment of fines and confiscation of street vendors' goods became the order of the day, forcing them to quit or go out of business. These states of affairs greatly limited the growth and expansion of some informal businesses as individuals either closed up their businesses or relocated to other areas where the situations were better.

Inadequate finances was another hinderance to the growth and development of informal activities. This greatly affected the existence of small businesses and made it expansion impossible. High transportation costs further constrained business transaction especially those that were located far away from the sources of raw materials. Production remained relatively low resulting to the non-enjoyment of economies of scale. The transportation of raw material or products produce by such businesses was a major problem. The population seize of Bamenda city being heterogeneous and dynamic, posed a huge problem to urban planners. The town maintained its aging structures that necessitated the raising of new once which unfortunate was hardly done. The state of roads in the area was not impressive especially the major stretch linking Bamenda, Bambui and Bambili. This made it very difficult for goods and persons to be transferred from one location to the other smoothly especially in the raining season when the situation was horrible.

Also, the presence of security forces alongside major roads in the area was a serious problem as they, at times, unnecessarily delayed movements of vehicles with the hope of attracting bribes or tips from them. A short distance that would have taken 30 minutes ended up taking an hour. In certain cases, some of the transporters deliberately refuse regularising the 
situation of vehicles by the non-payment of taxes, insuring the vehicles and the acquisition of other related documents. This therefore cut the attention of security agents who took advantage of situation in harassing them. Hence, much income was spent on transportation and settlement (bribing) of security officials rather than on business expansion which would have contributed to development of the sector. ${ }^{21}$

The diversity or cosmopolitan nature of the towns as well as varying informal activities ignited new problems as profits were not ploughed backed into the economy by businessmen and thus stifled the development of the area. They preferred investing in their various areas of origin. ${ }^{22}$ For instance, the Bamelikes and Igbos who dominated in informal activities around City Chemist and commercial avenue, the Borroros that clustered and operated informal businesses as tailoring, soya business, hairdressing in Old town and indigenes of Bui Division ploughed back profits to their areas of origin. It therefore means that these towns did not enjoy the multiplier effect of income raised from the informal sector to some extent when compared to other towns in Cameroon. This phenomenon was not typical to the area alone but also experienced by some towns in in the South West Region of Cameroon and the cases of Kumba and Tiko are distinct. ${ }^{23}$

The growth and development of the City of Bamenda, Bambui and Bambili brought unemployment as some of those who migrated into the area did not get the readily available jobs they envisaged. Unemployment rate was further enhanced by the increase number of graduates from institutions of higher learning in these towns. This led to the development of increased crimewave as some of the unemployed youths took unto cybercrimes as means of livelihoods. The area of study is well noted for this criminal activity and is among the leading centres in Cameroon. Some of them went into outright banditry. Insecurity became an urgent problem as the area was identified or associated to these crimes. Mile 4 Nkwen and Bambui are well noted for these crimes. Things became so horrible that the inhabitants took laws into their hands and jungle justice meted on anyone who indulged into these ungodly acts as they were beaten to death or burnt alive. The 1990s is well noted for these developments. Their numbers, nature, frequency and swiftness of crimes committed greatly affected informal businesses as the scale of havocs committed in some instances created panic and alarm in these towns, already aggrieved by economic crisis

${ }^{21}$ Edem

${ }^{22}$ Edem and inability of a majority of its inhabitants to provide for their daily needs.

The reliance on student population as consumers was another hurdle that affected the sector. During holidays the business enterprises suffered major setbacks with limited sales owing to the fact that their clients were on vacation. Besides, the real estate sector suffered as some of their clients abandoned their rooms or houses without payment of rents during this period. The transportation sector and other informal activities suffered major hitches as seen in the temporary closing down some of businesses. This greatly affected the profit margins of the informal sector within this area.

\section{CONCLUSION}

This paper examined urbanization and the rise of informal activities in City of Bamenda and environs. The findings revealed that there was a direct relationship between urbanization and the development of informal activities. The quest for better opportunities caused many to migrate into the area and the increased in the population of the area facilitated the development of informal activities. In this wise, the motorcycling sector, petti businesses, cobbling, real estate developments and communication related activities were the most sought-after opportunities. It was hoped that urbanisation would be a blessing for the area, but the reverse was true as poor road networks, increased criminality and crime wave, conflict between informal sector operators and municipal and taxation officials, couple with bribery and corruption, harassments and administrative bottlenecks among other difficulties rendered the sector ineffective in the development of the area.

\section{REFERENCES}

[1] Aloysius Ajab Amin. "Cameroon's Fiscal and Economic Growth”. (African Economic Research Consortium. Paper 85, November 1998.

[2] Amin, A. T. M. N. The informal sector paradigm: Analytical contributions and developmental role, editorial introduction of Regional Development Dialogue 17(1) (Spring): vi-xxviii.

[3] Amin, A. T. M. N. The informal sector paradigm: Analytical contributions and developmental role, editorial introduction of Regional Development Dialogue 17(1) (1996, Spring), xvii.

[4] Arouri, Mohamed, Youssef, Adel Ben, Nguyen-Viet, Cuong and Soucat, Agnès. "The Effects of Urbanization on Economic Growth and Human Capital Formation in Africa" (PGDA Working Paper No. 119, 2014.

${ }^{23}$ H.B. Nguendo Yongsi and Christopher R. Bryant, Population Dynamics and Urban Growth Challenges in Kumba, Southwest Province Cameroon, University of Montréal, 2008. 
[5] Bayie Kamanda, «Cameroon: The Retrenched Workers of the Civil Service and Parastatals. Assessing the Needs for the Reforms », Bulletin de l'APAD, 18, 1999, Accessed on September 72020.

[6] Burak Guneralp, Shuaib Lwasa, Hillary Masundire, Susan Parnell and Karen C Seto, "Urbanization in Africa: challenges and opportunities for Conservation", Environmental Research Letters: 13, 2018.

[7] Francis Azang Mboh, 51 Years, Trader, Nkewn, 25/09/2017; Charles Tifor Katu, 43 Years, Carpenter, Bambui, 19/09/2017; Mbanong Fedelis Andre, 60 Year, Farmer, Bamenda, 21/07/2017

[8] George, B. A. Ayetty. Africa in chaos. New York, United States of America: St Martin's Graffin, 1998.

[9] Hart K. Small Scale Entrepreneurs in Ghana and Development Planning, Journal of Development Studies, 28, 1970.

[10] Hull, R. W. African cities and towns before the European conquest. New York: W. W. Norton \& Company Inc, 1976.

[11] ILO $15^{\text {th }}$ International Conference of Labour Statisticians: Highlight of the Conference and Text of the Three Solutions Adopted. Geneva: Bulletin of Labour Statistics, 1992-2000.

[12] International Labour Office, Informal Sector in Africa. ILO/JASPA, A Ddiss Ababa, 1985.

[13] Mankon, 04/08/2017; love Chubu daisy, 66 Years, Retired teacher doing farming, Nkwen, 30/09/2017.

[14] NAB, Ad, (1927)4a, N0.277'/27, Assessment Report of Mezam Area in the Bamenda Division, Cameroon Province, 1927.

[15] Romanos, M. and C. Chifos. 1996. "Contributions of the urban informal sector to environmental management". Regional Development Dialogue 17(1).

[16] Romanos, M. and C. Chifos. 1996. "Contributions of the urban informal sector to environmental management". Regional Development Dialogue 17(1):122-155.

[17] Sheila Che Ako, 50 year, Farmer, Bambili, 23/08/2017; Roseline Azi Nwah, 45 years, Tailor,

[18] Schneider, F., Buehn, A. and Montenegro, C. E. "New Estimates for the Shadow Economies all Over the World". International Economic Journal, 24 (4), 2010.

[19] Suzanne Preston Blier. "The African Urban Past Historical Perspectives on the Metropolis in David Adjaye". Ed. African Metropolitan Architecture, London: Thames and Hudson, 2012.

[20] Teye, Joseph and Mariama Awumbila. "Factors Migration and Urbanization in Africa". (Centre for Migration Studies, University of Ghana, 2014.

[21] Teye, Joseph. "Urbanisation and Migration in Africa". (Expert Group Meeting, United Nations Headquarters in New York, 12 November, 2018.

[22] UNDESA (United Nations Department of Economic and Social Affairs). World Urbanization Prospects: 2014 Revision. (New York: United Nations Department of Social and Economic Affairs, 2014).
[23] UNDP (United Nations Development Programme). Human Development Report 2015: Work for Human Development. New York: United Nations Development Programme, 2015.

[24] United Nations. World urbanization prospects: The 2001 revision. New York: Upper Saddle River, 2002.

[25] United Nations. World urbanization prospects: The 2003 revision. New York: Upper Saddle River, 2004.

[26] Yongsi, H. B. Nguendo and Christopher R. Bryant, "Population Dynamics And Urban Growth Challenges in Kumba, Southwest Province Cameroon", University of Montréal, 2008. 